\title{
DISKURZIVNA ANALIZA ZAKONODAVNOG OKVIRA EUROPSKE UNIJE O CIRKULARNOJ EKONOMIJI
}

\author{
Valentino Petrović \\ Centar za demokraciju i pravo Miko Tripalo \\ Zagreb
}

\begin{abstract}
SAŽETAK
Dosadašnja istraživanja o razvoju cirkularne ekonomije u Europskoj uniji većim su djelom bila usmjerena na prednosti implementacije takvoga modela koje se najčešće dijele na okolišne i ekonomske. Ovaj će rad analizirati diskurs o cirkularnoj ekonomiji s drugačijeg gledišta, onoga kojemu je u središtu ljudsko zdravlje kao presudan faktor. Na temelju toga, pokušat će se odgovoriti na dva pitanja; kako su se mijenjali prioriteti i diskurs unutar zakonodavnog okvira Europske unije kada je riječ o cirkularnoj ekonomiji, te kako osvijestiti aktere da prilagode svoje ponašanje i djelovanje okolišnim normama. U analizi se koriste metode analize teksta i diskursa, kojima će se adresirati dosadašnja literatura i dokumenti Europske unije, prvenstveno paketi mjera o cirkularnoj ekonomiji, akcijski plan iz 2015. godine i novousvojene direktive. Ujedno, iskorištena je komparativna metoda za usporedbu 'starih' i 'novih' direktiva, odnosno diskursa u Europskoj uniji i Kini, te posljednja metoda, intervju s Davorom Škrlecom, bivšim zastupnikom u Europskom parlamentu i članom Kluba zastupnika Zelenih/Europskog slobodnog saveza. Rezultati su pokazali da je svaki novi paket Europske unije bio kvalitativno precizniji, ali da se sa stajališta ciljeva izlazilo u susret implementacijskim kapacitetima država članica. Na kraju, oblikovao se zasebni diskurs o cirkularnoj ekonomiji za čiju je sustavnu provedbu ipak nužno u središte postaviti pitanje zdravlja.

KLJUČNE RIJEČI: cirkularna ekonomija, Europska unija, direktiva 2018/851 o otpadu, Kina, policy, analiza diskursa, issue framing
\end{abstract}

\section{Kontakt autora:}

Valentino Petrović, Centar za demokraciju i pravo Miko Tripalo, Ilica 5, 10 ooo Zagreb. E-pošta: valentinopetrovic@hotmail.com 


\section{UVOD}

Politika zaštite okoliša danas se promatra iz smjera različitih aktera, poput nacionalnih vlada, privatnih kompanija, nevladinih organizacija i pojedinaca, koji svojim djelovanjem utječu na njezin razvoj te nastoje harmonizirati svoje ciljeve s ciljevima zelenih politika. U javnom diskursu o zelenim politikama sve češće se naglašavaju tri razine problema. Prvo, okolišni problemi koji su uzrokovani nedovoljnom brigom za zaštitu tla, vode i zraka. Drugo, društveni problemi poput nerazvijene svijesti o važnosti skrbi za okoliš koji mogu dovesti do povećane nezaposlenosti i siromaštva. Treće, ekonomski problemi koji su povezani s poslovanjem tvrtki i korporacija ili, najšire rečeno, djelovanjem tržišta (Geissdoerfer i sur. 2017, 757). Unatoč tome, zaštita okoliša ostaje koncept koji se (pre)često percipira utopijski jer posljedice nedovoljno razvijenih zelenih politika nisu vidljive danas, već će se očitovati tek u budućnosti.

Ovakav eskapistički način promišljanja prisutan je u državama članicama Europske unije, premda se svijest o problemu zagađenja okoliša počela razvijati 196o-ih godina u tadašnjoj Europskoj zajednici, dok su konkretne mjere i programi poduzeti početkom 1970-ih, najvećim djelom kao posljedica intervencije javnosti i proliferacije znanstvenih spoznaja o važnosti ekologije (McCormick 2010, 183-184). Potrebno je bilo pokrenuti val institucionalnih promjena kojima bi se stvorio pravni i zakonodavni okvir da politika zaštite okoliša postane dio šireg europskog plana. Prvi koraci bili su donošenje Akcijskog programa zaštite okoliša iz 1973. i Jedinstvenog europskog akta iz 1986. godine (McCormick 2010, 184). Wysokinska navodi program LIFE, uspostavljen 1992. godine, kojim je Europska unija nastojala financijski potpomognuti države članice $u$ ostvarivanju mjera zaštite okoliša, a uključivao je prije svega inovacije na lokalnoj razini. Njegova je namjena bila učinkovito iskorištavanje resursa i postizanje ekološke ravnoteže u sektorima poljoprivrede, ribarstva, energije i transporta (Wysokinska 2016, 6o-61).

Usporedno s razvojem politike zaštite okoliša, tijekom druge polovice 2o. stoljeća, u znanstvenim istraživanjima oblikovao se koncept cirkularne ekonomije na temelju ideja koje su se isprva pojavile u 18. i 19. stoljeću, a upozoravale su na ubrzan porast svjetske populacije i ograničenost prirodnih resursa (Kirchherr i sur. 2018, 264; Lacy i Rutqvist 2015, 20-21). Takve su ideje proizlazile iz različitih sustava mišljenja o navedenoj problematici, stoga se ne može sa sigurnošću tvrditi koji je autor ili znanstvenik zaslužan za uvođenje koncepta cirkularne ekonomije, već se njezina povijest promatra iz više pristupa koji uključuju izvedbenu ekonomiju, biomimikriju, industrijsku ekologiju, regenerativni dizajn i dr. (ellenmacarthurfoundation.org, 2019). Danas se cirkularna ekonomija promatra kao novi, učinkoviti i održivi model upravljanja prirodnim resursima i njome 
VALENTINO PETROVIĆ

DISKURZIVNA ANALIZA ZAKONODAVNOG OKVIRA EUROPSKE UNIJE

O CIRKULARNOJ EKONOMIJI

se aktivno bave različiti nevladini, nacionalni i međunarodni akteri među kojima vodeće mjesto zauzima Zaklada Ellen MacArthur (Tišma i sur. 2017, 229). Zaklada je osnovana 2010. godine ${ }^{1}$ i od tada se u okviru njezina rada objavljuju različita izvješća i knjige o cirkularnoj ekonomiji ${ }^{2}$ kojima se analiziraju pojedini dijelovi toga koncepta i područja na koja utječe. Jednako tako, Zaklada „služi kao centar za suradnju poslovnog sektora, kreatora politika i akademske zajednice“" (Geissdoerfer i sur. 2017, 759). Osim Zaklade, na razini država, Njemačka je imala predvodničku ulogu kada je riječ o integraciji „cirkularne ekonomije u nacionalno zakonodavstvo, što je učinila već 1996. godine stupanjem na snagu Zakona o promicanju kružnog gospodarstva i osiguravanju ekološkog odlaganja otpada“ (Su i sur. 2013 u: Geissdoerfer i sur. 2017, 759).

Unatoč hvalevrijednim aktivnostima Zaklade Ellen MacArthur u promicanju kružnoga modela, usmjerenje ovoga rada je na ulozi Europske unije i koracima koje je poduzela u cilju probuđivanja svijesti kod država članica o važnosti implementiranja mjera cirkularne ekonomije. Prve takve korake Europska unija poduzela je 2011. godine u dokumentima Predvodnička inicijativa za resursnu učinkovitost i Plan za resursnu učinkovitost, koji se smatraju polazištem oblikovanja cirkularnog modela, te u kojima se navode okolišne, ekonomske i društvene prednosti racionalnog korištenja prirodnih resursa (Tišma i sur. 2017, 238). Nakon toga, Europska unija je nastavila s aktivnostima u smjeru uvođenja zelenih politika u svoje zakonodavstvo što je rezultiralo paketima mjera o cirkularnoj ekonomiji, odnosno akcijskim planom i direktivama koje su predmet kasnije analize.

Cilj ovoga rada je istražiti koncept cirkularne ekonomije i njezin razvojni put u zakonodavstvu Europske unije. U prvome dijelu rada definirat će se cirkularna ekonomija, te će se usporediti s danas prevladavajućom, linearnom ekonomijom. Zatim će se kroz teorijski pregled literature i izvještaja Zaklade Ellen MacArthur prikazati prednosti i nedostaci implementacije cirkularnog modela. U trećem će se dijelu analizirati paketi mjera (iz 2014, 2015. i 2018. godine) Europske unije o cirkularnoj ekonomiji koji čine njezin zakonodavni okvir, s naglaskom na akcijski plan Europske komisije iz 2015. godine prigodnog naziva Zatvaranje kruga i četiri usvojene direktive iz 2018. godine. Jednako tako, analizom će se diferencirati diskursi

1 Više o povijesnom razvoju modela cirkularne ekonomije i školama mišljenja unutar kojih se koncept oblikovao, kao i znanstvenicima čiji je rad u različitim područjima i disciplinama utjecao na kreiranje pojma kružno gospodarstvo videti na: https://www.ellenmacarthurfoundation.org/circular-economy/concept/schools-of-thought i knjizi Okolišne politike i razvojne teme (Tišma i sur. 2017, 230-232).

Misija i ciljevi Zaklade Ellen MacArthur dostupni na: https://www.ellenmacarthurfoundation.org/our-story/mission

2 Publikacije Zaklade Ellen MacArthur dostupne za preuzeti ili kupiti na: https://www. ellenmacarthurfoundation.org/publications 


\section{6 \\ POLITIČKE PERSPEKTIVE \\ ČLANCI I STUDIJE}

i shvaćanje cirkularne ekonomije u Europskoj uniji i Kini s obzirom na to da je Kina svoj zakonodavni okvir o cirkularnoj ekonomiji donijela prije Europske unije i danas se po tome može smatrati uzorom mnogima (Tišma i sur. 2017, 236-237). To će biti učinjeno pregledom dosadašnjih empirijskih istraživanja o kineskom modelu cirkularne ekonomije iz kojih je vidljiv značajan diskurzivni pomak u odnosu na Europsku uniju. Nakon toga, slijedi rasprava iz koje će proizaći zaključak rada u kojem će se odgovoriti na dva pitanja: prvo, kako su se mijenjali prioriteti i diskurs Europske unije kada je riječ o cirkularnoj ekonomiji i, drugo, kako utjecati na svijest potrošača da promijene svoje navike i slijede principe cirkularnog modela.

\section{METODE PRIKUPLJANJA I ANALIZE PODATAKA}

Premda ima globalne dimenzije i široki raspon političkih, ekonomskih i društvenih koristi, cirkularna ekonomija se u Europskoj uniji razvila relativno kasno, stoga ne čudi manjak istraživanja čiji bi naglasak bio na rezultatima njezine implementacije u državama članicama. Iz tog razloga, ovaj će rad ponuditi pregled i analizu ključnih dokumenata Europske unije kojima se pokušao stvoriti zakonodavni okvir o cirkularnoj ekonomiji koji bi bio temelj buduće implementacije. U tome nam može poslužiti analiza sadržaja, no kako se ona danas može percipirati kao kvantitativna metoda u kojoj se „tekstualni podaci kodiraju u eksplicitne kategorije i zatim opisuju koristeći statistiku..." (Hsieh i Shannon 2005, 1278), precizirat ćemo terminologiju te iskoristiti analizu teksta i diskursa kao dvije kvalitativne metode istraživanja (Vromen 2018, 246).

Analiza teksta nam omogućuje fokusiranje na literaturu i službene dokumente, dok analiza diskursa uzima u obzir „širi društveni, politički i kulturni okvir (...) te je usmjerena na vokabular i strukturu teksta, odnosno (prikazuje) kako se korištenje pojedinih izraza mijenja kroz vrijeme“" (Vromen 2018, 251). To je važno jer ćemo u ovom radu istražiti implikacije provedbe cirkularnog modela, njezine okolišne, društvene i ekonomske prednosti. Istovremeno, analizirat ćemo promjene u prioritetima i diskursu Europske unije o cirkularnoj ekonomiji s naglaskom na tri paketa mjera, odnosno usvojene direktive iz 2018. godine koje su oblikovane unutar vidljivog cirkularnog diskursa i one prethodne direktive $\mathrm{u}$ kojima se cirkularna ekonomija ne spominje. Jednako tako, u kontekstu istraživanja, neophodno je naglasiti da „diskurs nije politički neutralan nego da utjelovljuje odnose moći, uspostavljajući ih, održavajući ili razgrađujući“ (Petković 2014, 49), što će nam poslužiti za razumijevanje stavova javnog i privatnog sektora, te ostalih aktera koji svojim djelovanjem kontroliraju upravljačke mehanizme cirkularne ekonomije i teže ostvariti svoje javne ili partikularne interese. 


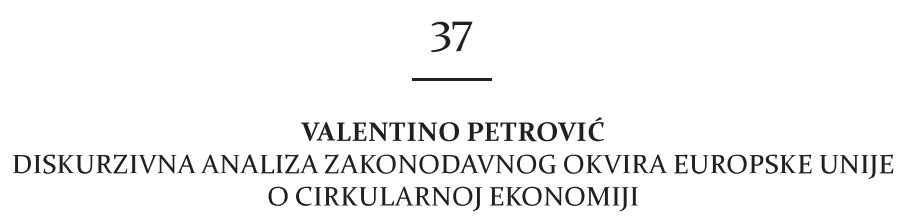

Uz analizu teksta i diskursa, kao istraživačka metoda iskorištena je komparativna analiza na dva načina. Prvo, na primjeru novousvojene direktive o otpadu iz 2018. godine i direktive o otpadu iz 2008. godine, uspoređivat ćemo promjenu diskursa prema cirkularnom modelu unutar zakonodavstva Europske unije, kao i promjene unutar ranije navedenih paketa. Drugo, uspoređivat će se diskurs o cirkularnoj ekonomiji između Europske unije i Kine na policy razini. U poglavljima posvećenima Europskoj uniji vidjet ćemo što je to potaknulo Europsku uniju da primjeni načela kružnoga modela i prenese ih u svoje zakonodavstvo. U poglavlju posvećenom Kini uočit ćemo razlike u pristupu navedenoj problematici, te krajnjim ciljevima koje Kina želi ostvariti implementiranjem cirkularne ekonomije. Kao posljednja metoda istraživanja iskorišten je ekspertni polustrukturirani intervju s Davorom Škrlecom, bivšim hrvatskim zastupnikom u Europskom parlamentu i članom Kluba zastupnika Zelenih/Europskog slobodnog saveza, proveden 3. rujna 2019. godine. Osim njegova mandata u Europskom parlamentu, razlog zašto je proveden jedan intervju leži u činjenici da se sam Škrlec profesionalno bavi pitanjem cirkularne ekonomije i bio je član Odbora za okoliš, javno zdravlje i sigurnost hrane (europarl.europa.eu, 2019). Ujedno, ovaj rad ne teži problematiziranju cirkularne ekonomije iz perspektive različitih političkih opcija ili ideologija, stoga se ekspertni intervju za dubinsku analizu čini primjerenim.

Koristeći navedene istraživačke metode promatrat ćemo kako je cirkularna ekonomija došla na dnevni red odlučivanja u Europskoj uniji i kako je uokvirena u analiziranom zakonodavnom okviru (paketi mjera, akcijski plan, direktive). U tome će nam pomoći metodološke pretpostavke policy ciklusa ili procesa stvaranja javnih politika (Petak i Petek 2014, 133-136), ali najvažnije od svega iskoristit ćemo issue framing (Jerković i Petak 2017), odnosno davanje okvira problemu, kao alat za proširivanje i redefiniranje prioriteta cirkularne ekonomije kojim se ostvaruje posljednji korak u zaokruživanju diskursa problematike ovoga rada. Cjelokupna analiza bit će potkrijepljena korištenjem primarnih izvora, dakle službenih dokumenata i izvješća Europske unije, odnosno direktiva, te sekundarnih izvora koji uključuju dosadašnju literaturu i istraživanja o cirkularnoj ekonomiji.

\section{Cirkularna EKONOMIJA, DEFINICIJA I TEMELJNE ODREDNICE}

Da bismo na ispravan način definirali koncept cirkularne ekonomije i upoznali se sa svim njezinim karakteristikama najprije je potrebno reći nešto više o linearnom modelu ili linearnoj ekonomiji koja umnogome opisuje tradicionalan način bavljenja pitanjima otpada, resursa i koja donosi ekonomske gubitke za proizvođače i potrošače (Bačova i sur. 2016, 2; Bourguignon 2016, 1-2). To je način upravljanja u kojem dolazi do ,isko- 


\section{8 \\ POLITIČKE PERSPEKTIVE \\ ČLANCI I STUDIJE}

rištavanja i transformacije prirodnih resursa u proizvode; kasnije te proizvode kupuju potrošači koji ga bacaju nakon što je ispunio njihove potrebe (...) takav model zanemaruje visoke ekonomske, društvene i troškove za okoliš (...) stoga je neodrživ u dugoročnom pogledu“" (Bačova i sur. 2016, 2). Upravljanje resursima time je simplificirano i jednokratno jer proizvođači i potrošači ne uzimaju u obzir dugoročne ciljeve održivog razvoja i prednosti sustava koji uključuje recikliranje iskorištenih proizvoda, što posljedično dovodi do sve većih ekoloških neravnoteža. U studiji Službe Europskog parlamenta za usluge parlamentarnih istraživača (European Parliamentary Research Service - EPRS) navodi se da u Europi danas prevladava upravo linearan model upravljanja otpadom koji podrazumijeva postojanje neograničenih resursa i materijala za proizvodnju, ali i stvara pretjeranu ovisnost o resursima izvan Europe (Hollins i sur. 2017, 15-16). Druga studija, ona Zaklade Ellen MacArthur (2014, 12), slijedi sličnu argumentaciju i u njoj se problematiziraju ograničenja linearne ekonomije poput rizika s kojima su suočene tvrtke pri nabavi resursa čije cijene više nisu predvidljive. Jednako tako, nedostatke linearnog modela istraživači Zaklade vide $u$ nesigurnim lancima nabave, deterioraciji kvalitete hrane i pretjeranoj potrošnji energije (Zaklada Ellen MacArthur Vol. 3 2014, 12). Cirkularna ekonomija vodi se drugačijom ekološko-ekonomskom paradigmom i, teoretski, izravno pristupa ograničenjima izazvanim korištenjem linearnog modela. Ipak, kasnija analiza pokazat će da je praktična primjena cirkularnog modela suočena s brojnim izazovima koji uključuju, između ostalog, različite interese država članica Europske unije i privatnog sektora.

Pri definiranju cirkularne ekonomije važno je naglasiti da ona nema jednu, univerzalnu definiciju (Tišma i sur. 2017, 229), već se različiti autori i znanstvenici u svojim radovima nastoje opredijeliti za onu koja je za potrebe njihovih istraživanja najprikladnija. Pošto je ovaj rad primarno politološkog karaktera i ne ovisi toliko o samoj definiciji cirkularne ekonomije, koja često uključuje tehničke termine specifične za prirodne znanosti, te u manjoj mjeri društvene, odlučeno je da nema potrebe za stvaranjem nove definicije, već će biti iskorištene one koje objedinjuju njezine glavne osobine. Osim pukog upoznavanja s pojmom cirkularne ekonomije, njezino definiranje je važno jer se često uz nju spominje sintagma održivi razvoj, te odnos dva navedena koncepta nerijetko ostaje mistificiran nedovoljno jasnom eksplanacijom njihovih temeljnih karakteristika. Problematiziranje diskursa između ova dva termina poslužit će u kasnijoj raspravi u kojoj će se navesti nešto više o samom održivom razvoju.

Često se u literaturi koristi definicija Zaklade Ellen MacArthur u kojoj se navodi da je cirkularna ekonomija usmjerena prema ostvarivanju „razvojnog ciklusa koji štiti i povećava prirodni kapital, optimizira korištenje prirodnih resursa i minimizira sistemske rizike kroz upravljanje 
VALENTINO PETROVIĆ

DISKURZIVNA ANALIZA ZAKONODAVNOG OKVIRA EUROPSKE UNIJE

O CIRKULARNOJ EKONOMIJI

ograničenim i obnovljivim resursima“ (Tišma i sur. 2017, 229). Provođenjem takvih mjera ne utječe se isključivo na sektor zaštite okoliša, već ono podrazumijeva međusektorski pristup u koji su uključeni različiti akteri i različite grane industrije, poljoprivreda, poduzetnici, te krajnji korisnici potrošači (Bačova i sur. 2016, 2). Implementacija modela cirkularne ekonomije zahtijeva komplementarne mjere u procesu stvaranja novih proizvoda, te utilitaristički pristup kojim se ostvaruje višestruka korist za javni i privatni sektor čije je stavove, ipak, teško harmonizirati.

Kirchherr i sur. (2018) u svojoj analizi koriste široku definiciju cirkularne ekonomije koja pretpostavlja ostvarivanje ciljeva održivog razvoja te ističu pitanje društvene korisnosti takvoga modela. Tvrde da se cirkularna ekonomija temelji na „smanjivanju, alternativnoj upotrebi i recikliranju (...) materijala $u$ procesu stvaranja, distribucije i potrošnje (...) s ciljem postizanja održivog razvoja, što implicira stvaranje više kvalitete okoliša, ekonomskog prosperiteta i društvene pravednosti..." (Kirchherr i sur. 2017, 224-225 u: Kirchherr i sur. 2018, 264). Ova definicija je točna i na ispravan način opisuje dugoročne posljedice implementiranja održivih modela naglašavajući okolišne, ekonomske i društvene prednosti sinergije cirkularne ekonomije i održivog razvoja. No, u ovom radu smo se ipak odlučili za treću definiciju koja taj odnos analizira znatno kompleksnije.

U dvjema ponuđenim definicijama mogu se primijetiti sličnosti koje će se, jednako tako, očitovati u posljednjoj definiciji, ali razlog radi kojega je ona potrebna leži u činjenici da su autori treće definicije pretpostavili i dokazali konceptualnu i provedbenu razliku cirkularne ekonomije i održivog razvoja. Tako Geissdoerfer i sur. (2017) jasno diferenciraju navedene modele tvrdeći da je cirkularna ekonomija „regenerativni sustav $u$ kojem su upotreba resursa, otpad, zračenje i potrošnja energije minimizirani usporavanjem, zatvaranjem i ograničavanjem materijala i energetskih petlji“ (Geissdoerfer i sur. 2017, 759). Više o odnosu cirkularne ekonomije i održivog razvoja bit će prikazano u diskusiji, no zasad je važno napomenuti da će se u cjelokupnoj analizi kao radna definicija cirkularne ekonomije iskoristiti posljednje navedena jer je cilj izbjeći monolitno shvaćanje da su ova dva koncepta nedjeljiva i da jedan neizbježno proizlazi iz drugoga. Osim toga, ova definicija omogućuje da na temelju analize zakonodavstva Europske unije o cirkularnoj ekonomiji i kasnije diskusije logički povežemo rad $\mathrm{u}$ koherentnu cjelinu i ponudimo optimalan zaključak i prijedloge kako pomiriti različita shvaćanja cirkularne ekonomije i održivog razvoja, te odgovorimo na istraživačka pitanja. 


\section{PREDNOSTI I IZAZOVI IMPLEMENTACIJE CIRKULARNOG MODELA}

Prednosti korištenja cirkularnog modela višestruke su, ali ih se najčešće dijeli u dvije ponekad suprotstavljene kategorije: okolišne i ekonomske prednosti (Bourguignon 2016, 3). Takvo, pomalo manihejsko, shvaćanje u kojem su u odnos dovedeni interesi prirode i profita nastoji se racionalizirati teorijom usmjerenom na resurse ${ }^{3}$. Njome se objašnjava da „ulaganja u okolišni sektor mogu dovesti do povećanja profita" (Park i sur. 2010, 1494), odnosno da privatni sektor svojim aktivnostima može generirati ekonomski rast, što dovodi do obostrane koristi (Park i sur. 2010). U kontekstu cirkularne ekonomije Andersen $(2006,134)$ smatra da bi bilo racionalno očekivati od privatnog sektora da poštuje norme i maksime kružnoga modela ukoliko će to povećati konačan iznos zarade koji ostvaruje svojim djelovanjem, međutim, navodi da niti kod donositelja odluka, ni kod privatnog sektora još nije razvijena svijest o prednostima takvog načina upravljanja resursima (Andersen 2006, 134).

Bourguignon polazi od pretpostavke da će implementacija cirkularne ekonomije dovesti do značajnog poboljšanja okolišnih uvjeta čime će se smanjiti pritisak i negativne posljedice ljudskog djelovanja na prirodu. U kategoriju okolišnih prednosti navodi „značajno smanjenje emisije stakleničkih plinova putem efikasnijeg upravljanja otpadom". Jednako tako, naglašava „smanjenu upotrebu resursa (poput energije, vode, tla) u proizvodnji, što će se pozitivno odraziti na klimatske promjene“. Na kraju, cirkularna ekonomija „ublažit će rizike povezane s nabavom sirovina, poput cjenovne volatilnosti, dostupnosti sirovina i ovisnosti o uvozu" (Bourguignon 2016, 3-4). Slijedom ove argumentacije može se zaključiti da je teorija usmjerena na resurse na točan način predvidjela međuovisnost prirode i profita, barem u ovom kontekstu.

Cirkularna ekonomija implicira inovativne načine upravljanja resursima, a ekonomske prednosti takvoga modela proizlaze upravo iz novih tehnologija koje poslovni sektor koristi za stvaranje dodatne vrijednosti i unaprjeđenje svog rada (Zaklada Ellen MacArthur Vol. 2 2013, 9-10). Inovacije i moderne tehnologije povezane su s ostalim prednostima kružnoga modela poput otvaranja radnih mjesta i pojačane interakcije između proizvođača i potrošača. Predviđeno je da se implementacijom cirkularne ekonomije stvori novi oblik suradnje više sektora u procesu proizvodnje, ponajviše na lokalnoj razini, što će dovesti do rasta zaposlenosti; potrošači tada više neće koristiti proizvode jednokratno već će ih nakon prvotnog korištenja proizvođači moći unaprijediti za buduću primjenu (Zaklada 
VALENTINO PETROVIĆ

DISKURZIVNA ANALIZA ZAKONODAVNOG OKVIRA EUROPSKE UNIJE

O CIRKULARNOJ EKONOMIJI

Ellen MacArthur Vol. 2 2013, 9-10; Zaklada Ellen MacArthur Vol. 1 2013, 11).

Kada je riječ o izazovima i nedostacima implementacije cirkularnog modela Preston (2012) navodi sljedeće. Prvo, smatra da je danas cjelokupna infrastruktura u procesu proizvodnje usmjerena prema iskorištavanju fosilnih goriva u cilju postizanja neprestanog industrijskog rasta, što je u suprotnosti s cirkularnim modelom koji pretpostavlja diversifikaciju resursa. Drugo, različite interesne grupe mogu utjecati na političku volju da se cirkularne mjere ipak ne uvedu u okviru policy procesa jer će to podrazumijevati više cijene određenih resursa. Treće, unatoč dugoročnim koristima kružnog modela, tvrtke se susreću s izazovom i rizikom prilagođavanja novom načinu proizvodnje, što uključuje uvođenje nove opreme, strojeva i podjelu rada. Četvrto, u procesu proizvodnje više ne bi sudjelovala jedna tvrtka već više njih iz različitih država te stoga potrebna razmjena informacija i stvaranje novih lanaca nabave. Peto, i možda najvažnije, nemogućnost utjecaja na svijest potrošača da promijene svoje navike u smislu odlaganja otpada i da prepoznaju vrijednost cirkularne ekonomije (Preston 2012, 14-15).

Nadalje, pozvat ćemo se na istraživanje Kirchherra i sur. (2018) kao važnu referencu s empirijskom podlogom u kojem su autori nastojali klasificirati barijere implementaciji cirkularne ekonomije u Europskoj uniji. Tijekom istraživanja provedeni su intervjui i ankete s predstavnicima poslovnog sektora i nacionalnih vlada država članica Europske unije, te su rezultati pokazali da se prepreke mogu podijeliti u četiri kategorije: kulturalne, regulatorne, tržišne i tehnološke. ${ }^{4}$ Odgovore koje su autori dobili tijekom intervjua i u anketi kodirali su u navedene kategorije. Istraživanje je pokazalo da su „kulturalne prepreke, ponajprije odgovori 'nedostatak interesa i svijesti potrošača' i 'neodlučna kultura poduzeća' pojavljuju kao najčešće prepreke cirkularnoj ekonomiji..." (Kirchherr i sur. 2018, 270). Zanimljivo, odgovori koji pripadaju skupini „tehnoloških prepreka, poput 'sposobnosti za ponovnu proizvodnju visokokvalitetne robe' nalaze se na posljednjem mjestu" (Kirchherr i sur. 2018, 270).

Na kraju, valja navesti izazov kruženja otrovnog otpada u procesu recikliranja, što neposredno utječe na ljudsko zdravlje (Bilitewski 2012; Grundmann i sur. 2013; Lahl and Zeschmar-Lahl 2013). Prema procjenama, gotovo „80\% elektroničkog otpada transportira se iz razvijenih država u države u

4 Autori su nastojali odgovoriti na pitanje „koje su glavne prepreke za usporavanje tranzicije Europske unije prema cirkularnoj ekonomiji? (...) Podaci su prikupljeni tijekom 2017. godine. Istraživanje je uključivalo tri razine: analizu dokumentacije, polustrukturirane intervjue i anketu. Ispitanici su bili iz cijele Europe, npr. Belgije, Njemačke, Nizozemske, Portugala, Švedske i Ujedinjenog Kraljevstva“" (Kirchherr i sur. 2018, 265). Naslov istraživanja: Barriers to the Circular Economy: Evidence from the European Union (EU). 
razvoju u Aziji i Africi gdje se recikliraju i prenamijenjuju zbog niske cijene rada i manjka kontrole..." (Grundmann i sur. 2013, 2).

\section{STVARANJE ZAKONODAVNOG OKVIRA O CIRKULARNOJ EKONOMIJI U EU}

Premda su i prije 2011. godine unutar Europske unije postojale inicijative za stvaranje obuhvatne strategije kojom bi se kontrolirao i zaštitio sektor okoliša, kao referentno razdoblje kojim ćemo započeti analizu zakonodavnog okvira o cirkularnoj ekonomiji u Europskoj uniji uzeli smo ono nakon 2011. jer tada nastaju ključni dokumenti o cirkularnom modelu što je, između ostalog, i navedeno u literaturi u uvodnom dijelu rada (Tišma i sur. 2017). Prvi paket Europske komisije o cirkularnoj ekonomiji nastaje 2014. godine i nosi naziv Prema kružnom gospodarstvu: program nulte stope otpada za Europu (Towards a Circular Economy: A Zero Waste Programme for Europe). Plan je bio „transformirati Europsku uniju u cirkularnu ekonomiju do 203o. godine, što se trebalo postići izmjenama šest direktiva o otpadu“ (Scharff 2018,2 ). Od samog početka proučavanja dokumenta, pa i u njegovu naslovu uočava se promjena diskursa prema ostvarivanju ciljeva cirkularne ekonomije. Tako se u uvodu na općenitoj razni čitatelja upoznaje s modelom cirkularne ekonomije i njezinim temeljnim principima, dok se u drugome dijelu navode tržišne i okolišne prednosti prema kojima bi „sprječavanjem stvaranja otpada, ekološkim dizajnom, ponovnom uporabom otpada i sličnim mjerama, poduzeća u EU mogla ostvariti neto uštedu od 600.00o.ooo.ooo eura (...), a godišnje emisije stakleničkih plinova istovremeno bi se smanjile za 2 do 4\%" (eurlex.europa.eu 2014). U direktivama koje su sadržane u paketu, Europski parlament i Vijeće Europske unije predlažu izmjenu prijašnjih direktiva ${ }^{5}$, čime bi se ostvarilo povećanje „recikliranja komunalnog otpada na barem $70 \%$ do 2030, povećanje stope recikliranja ambalažnog otpada na $80 \%$ do 2030. (...) zabranu odlaganja otpada koji se može reciklirati do 2025, dok bi države članice trebale uložiti napore za prestanak odlaganja otpada do 2030." (eur-lex.europa.eu 2014, 10).

Na samom početku, Scharff tvrdi, plan je bio pozitivno prihvaćen, poglavito zbog problematike koju je adresirao te su pozdravljeni pokušaji da se unutar Europske unije harmoniziraju okolišni ciljevi osnivanjem posebnih mehanizama izvještavanja i nadziranja provedbe proklamiranih ideja. Međutim, velika je pozornost bila usmjerena na komunalni otpad,

5 Predložene su izmjene direktive 20o8/98/EZ o otpadu, 94/62/EZ o ambalaži i ambalažnom otpadu, 1999/31/EZ o odlagalištima otpada, 200o/53/EZ o otpadnim vozilima, 2006/66/EZ o baterijama i akumulatorima i o otpadnim baterijama i akumulatorima, te 2012/19/EU o otpadnoj električnoj i elektroničnoj opremi (eur-lex.europa.eu 2014). 
VALENTINO PETROVIĆ

DISKURZIVNA ANALIZA ZAKONODAVNOG OKVIRA EUROPSKE UNIJE

O CIRKULARNOJ EKONOMIJI

postotci recikliranja koje države članice trebaju ostvariti bili su previsoki, te je problem bio neuključivanje aktera poput istraživača i sveučilišta u kreiranje strategije, koja je većim dijelom bila proizvod analize stručnjaka unutar institucija Europske unije. Komisija je pravovremeno intervenirala te su sredinom 2015. godine provedene konzultacije koje su uključile široki broj aktera, između ostalog, predstavnike interesnih skupina i poslovnog sektora (Scharff 2018, 2-5). Iz istih su razloga povučeni prijedlozi izmjena direktiva, što je otvorilo prostor donošenju novog paketa o cirkularnoj ekonomiji u prosincu 2015. koji je sadržavao akcijski plan i četiri nova prijedloga direktiva s novim ciljevima koji su postavljeni pred države članice (Bourguignon 2016, 5).

U planu naziva Zatvaranje kruga - akcijski plan EU-a za kružno gospodarstvo (Closing the Loop - An EU Action Plan for the Circular Economy) ponovno se detaljno analiziraju prednosti koje bi države članice, ali i Europska unija kao zajednica, ostvarile implementacijom mjera cirkularne ekonomije. Osim dostizanja višeg stupnja ekološkog standarda koji je prethodni plan naglasio, Europska komisija sada polazi od pretpostavke da će se prelaskom na novi, cirkularni model „povećati konkurentnost EU-a, čime će se pridonijeti stvaranju novih poslovnih prilika, te inovativnih i učinkovitih načina proizvodnje i potrošnje (...) na lokalnoj razini otvarat će se nova radna mjesta na svim razinama kvalifikacija“ (eur-lex.europa. eu 2015, 2).

Akcijskim planom Europska komisija je obuhvatila pet prioritetnih područja za razvoj kružnog i održivog gospodarstva, te za svako ističe zašto je ono važno, odnosno na koji način implementacija mjera cirkularne ekonomije može pridonijeti njegovom unaprjeđenju. Ističu se: a) važnost recikliranja plastike, b) smanjenje rasipanja hrane, c) racionalizacija korištenja ključnih sirovina, d) recikliranje građevinskog otpada i e) prenamjena materijala na bio osnovi (eur-lex.europa.eu 2015, 14-19). U okviru predloženih izmjena direktiva redefinirani su ciljevi za države članice u pogledu recikliranja koji su smatrani dovoljno ambicioznima, te izvedivijima u odnosu na one iz 2014. godine. Tako se navodi da je cilj recikliranje „65\% komunalnog otpada do 2030. (...) 75\% ambalažnog otpada do 2030. (...) smanjenje odlaganja otpada na najviše $10 \%$ svog otpada do 2030. (...) uvođenje gospodarskih poticaja za proizvođače da na tržište stavljaju ekološki prihvatljivije proizvode“" (europa.eu 2015). Ti su ciljevi smanjeni za pet postotnih bodova naspram onih iz prvog paketa o cirkularnoj ekonomiji iz 2014. godine, što je razumljivo s obzirom na, između ostalog, nejednake apsorpcijske kapacitete država članica. Ovim je paketom Komisija pružila mogućnost Estoniji, Grčkoj, Hrvatskoj, Malti, Rumunjskoj i Slovačkoj da zatraže odgodu od pet godina za ispunjavanje navedenih ciljeva recikliranja komunalnog otpada i smanjenja odlaganja otpada (Scharff 2018,6), pa se i 
na tom području vidi racionalizacija u pristupu gospodarenja otpadom, te uzimanje u obzir kritika na račun prvotnog plana iz 2014. godine.

Prije posljednjeg dijela analize u kojem će biti predstavljene direktive usvojene 2018. godine kojima je Europska komisija revidirala dotadašnje zakonodavstvo unutar Europske unije, ukratko će biti prikazano izvješće Europske komisije o akcijskom planu iz 2015. godine. U dosadašnjoj se analizi može primijetiti konvergencija prema onome što bi se možda preambiciozno moglo nazvati idealima cirkularne ekonomije. Tome u prilog možemo navesti tvrdnju da su u drugom paketu o cirkularnoj ekonomiji rezultati koje države članice trebaju ostvariti, jednako kao i mjere kojima će se oni postići, prilično specificirani. Slijedom toga, u izvješću se navodi da se u akcijskom planu prvi puta „promicao sustavni pristup u svim vrijednosnim lancima. Na temelju njega Komisija je integrirala načela kružnog gospodarstva u proizvodnju i potrošnju plastike, gospodarenje vodama, prehrambene sustave..." (eur-lex.europa.eu 2019, 1). Osim toga, akcijskim planom se naglasila heterogenost aktera koji sudjeluju u procesima proizvodnje i potrošnje resursa, među kojima su istaknuti građani država članica kao dionici čiju je ulogu potrebno ojačati, što se treba postići pravovremenim informiranjem o kvaliteti i trajnosti proizvoda koje koriste. Jednako tako, važnu ulogu u provođenju mjera cirkularne ekonomije imaju privatni akteri, napose poduzeća. Europska je komi-

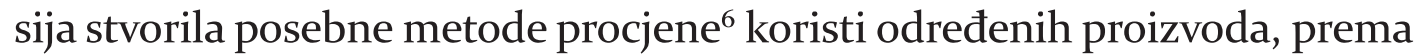
kojima će se mjeriti njihova ekološka prihvatljivost, čime će se pomoći poduzećima da prilagode svoje poslovanje ekološkim zahtjevima (eur-lex. europa.eu 2019, 3).

Kako ne bi došlo do perpetuiranja jednostranog ispunjavanja ciljeva, akcijskim se planom predložila razmjena iskustava država članica i zajednička provedba ideja o cirkularnoj ekonomiji, tijekom koje bi Europska komisija pružala pomoć sudjelovanjem svojih stručnjaka (eur-lex.europa. eu 2019, 3-5). Međutim, to je vrlo teško postići uzevši u obzir razlike između država članica kada je riječ o kontroli otpada, odnosno recikliranju njegovih posebnih vrsta. Pozivajući se na podatke Eurostata iz 2016. godine, Bourguignon navodi da Njemačka prednjači u recikliranju komunalnog otpada s gotovo 50\%, dok države poput Malte, Rumunjske i Slovačke ne dostižu niti 10\%. Recikliranje ambalažnog otpada se susreće s drugom vrstom problema jer ono uključuje različite vrste, te se, primje-

6 „Metode mjerenja ekološkog otiska proizvoda (Product Environmental Footprint, PEF) i ekološkog otiska organizacija (Organization Enviroemental Footprint, OEF), koje je razvila Komisija, omogućuju poduzećima da iznose pouzdane, ponovljive i usporedive tvrdnje o prihvatljivosti proizvoda za okoliš (...) Približno zoo poduzeća iz 27 različitih sektora i više od 2000 dionika pet je godina radilo na ispitivanju tih metoda, koje smatraju najboljom praksom za procjenu životnog ciklusa“ (eur-lex.europa.eu 2019, 3). 
VALENTINO PETROVIĆ

DISKURZIVNA ANALIZA ZAKONODAVNOG OKVIRA EUROPSKE UNIJE

O CIRKULARNOJ EKONOMIJI

rice, na razini EU-28 najviše reciklira papir (85\%), dok se u najmanjem udjelu reciklira plastična ambalaža (37\%). Rastući problem u Europskoj uniji zasigurno predstavlja i godišnji rast otpada uzrokovan električnom i elektroničkom opremom 3-5\% (Bourguignon 2018, 2-3).

Iz izvješća Službe Europskog parlamenta za usluge parlamentarnih istraživača, nastalog u ožujku 2018. godine, može se zaključiti da nije bilo ujednačenog stava oko akcijskog plana i prijedloga direktiva. Najveći otpor paket je doživio od strane nevladinih udruga koje su zahtijevale „uvođenje ciljeva za prevenciju otpada od hrane i morskog otpada (...) kao i kažnjavanje za spaljivanje neobrađenog otpada" (Bourguignon 2018, 9). Poslovni sektor je pozdravio napore Europske unije da harmonizira ciljeve recikliranja u državama članicama, ali su istovremeno upozoravali na važnost kvalitetne implementacije. Nacionalni parlamenti država članica su, pak, upozorili da su pojedine stavke paketa protivne načelu supsidijarnosti, poput ujednačavanja definicija i izvještavanja Europske unije o provedenim mjerama (Bourguignon 2018, 8-10).

Unatoč različitim mišljenjima oko problematike cirkularne ekonomije u Europskoj uniji, akcijski se plan iz 2015. godine i njegove direktive smatraju temeljem posljednjeg paketa analiziranog $\mathrm{u}$ ovome radu, onoga iz 2018. godine, u kojemu su, između ostalog, usvojene izmijenjene direktive s novim ciljevima za države članice. Osim toga, paket je jasno definirao strategiju7 kojom će se mjeriti napredak država članica prema ostvarenju cirkularne ekonomije. Strategija obuhvaća deset pokazatelja, te je definirana njihova relevantnost, odnosno alati Europske unije kojima će se ostvariti. Pritom je strategija podijeljena u četiri faze: proizvodnja i potrošnja, gospodarenje otpadom, sekundarne sirovine, te konkurentnost i inovacije (eur-lex.europa.eu 2018, 3-4).

No, najvažnija promjena u paketu iz 2018. godine očituje se u usvajanju četiri nove direktive koje postavljaju pred države članice fiksne rokove za ispunjavanje ciljeva cirkularne ekonomije; to su direktive o: a) otpadu, b) ambalaži i ambalažnom otpadu, c) odlagalištima otpada i d) baterijama i akumulatorima, otpadnim baterijama i akumulatorima, te otpadnoj električnoj i elektroničnoj opremi (davor-skrlec.eu 2019). Promatrajući navedene direktive uočava se ono što smo ranije nazvali promjenom diskursa o cirkularnoj ekonomiji jer su diskurzivni pomaci unutar novih direktiva vidljivi, prvo, u njihovom odnosu prema direktivama koje su zamijenili,

7 Strategija je sadržana u dokumentu Komunikacija Komisije Europskom parlamentu, Vijeću, Europskom gospodarskom i socijalnom odboru i Odboru regija: o okviru za praćenje kružnog gospodarstva. U dokumentu su jasno navedene faze i pokazatelji napretka prema cirkularnoj ekonomiji, te prvi zaključci o provođenju takvog modela. Dokument dostupan na https://eur-lex.europa.eu/legal-content/HR/TXT/PDF/?uri=CELEX:52018DCoo29\&fro $\mathrm{m}=\mathrm{EN}$. 


\section{6 \\ POLITIČKE PERSPEKTIVE \\ ČLANCI I STUDIJE}

i drugo, u odnosu na prvi paket kojim smo započeli analizu, onaj iz 2014. godine. Osim toga, longitudinalnom analizom i komparativnom metodom možemo promatrati kako su se ciljevi Europske unije mijenjali, te kako su bili formulirani kroz sadržaj svakog novog zakonodavnog paketa. Pa je tako očiti zaokret u sadržaju direktive o otpadu iz 2018. godine u odnosu na direktivu koju je zamijenila, onu iz 20o8. godine. U prvom članku nove direktive jasno se daje do znanja da Europska unija teži prema novome, cirkularnom modelu, te je i sama upotreba terminologije prilagođena tome. Novom direktivom se:

„utvrđuju mjere za zaštitu okoliša i zdravlja ljudi sprečavanjem ili smanjenjem nastanka otpada (...) smanjenjem ukupnog utjecaja uporabe resursa i povećanjem učinkovitosti takve uporabe, što je ključno za prijelaz na kružno gospodarstvo i osiguravanje dugoročne konkurentnosti Unije (Direktiva 2018/851 2018, 150/120).

U prvome se članku direktive iz 20o8. godine tvrdi da se „utvrđuju mjere za zaštitu okoliša i zdravlja ljudi sprečavanjem ili umanjenjem štetnih učinaka proizvodnje i gospodarenja otpadom i umanjenjem sveukupnih učinaka uporabe resursa, te poboljšanjem efikasnosti te uporabe“ (Direktiva 20o8/98/EZ 20o8, 104). Jednako tako, u novoj se direktivi navodi da je potrebno uvesti definicije različitih vrsta otpada i postrožiti ciljeve za države članice kako bi oni reflektirali nastojanje Europske unije da se transformira prema kružnome modelu, dok prvotna direktiva iskazuje tek nastojanje Unije za donekle preciznijim definiranjem otpada, oporabe i zbrinjavanja (Direktiva 2018/851 2018, 150/109-110) (Direktiva 2008/98/ EZ 2008, 99-100).

Naravno, Europskoj uniji može se prigovoriti da su ovo samo kozmetičke promjene kojima de jure iskazuje potrebu za promjenom dosadašnjeg smjera. Međutim, direktiva o otpadu iz 2018. godine daje jasne definicije i stavlja nove ciljeve pred države članice koje trebaju ispuniti u narednom razdoblju. Tako se uvode definicije neopasnog otpada, komunalnog otpada i građevinskog otpada, te se revidiraju definicije biootpada i gospodarenja otpadom (Direktiva 2018/851 2018, 150/120-121). Ove nam definicije nisu toliko važne u smislu prelaska na cirkularan model, već odražavaju prioritete Europske unije u smislu diskursa kojem je u središtu termin otpad (waste) i njegove različite vrste i kategorije u svim analiziranim dokumentima. Više o tome bit će rečeno u sljedećem poglavlju koje će uspoređivati diskurs o cirkularnoj ekonomiji u Europskoj uniji i Kini. Prije toga, potrebno je spomenuti ciljeve koji su postavljeni pred države članice kada je riječ o recikliranju. Direktivom o otpadu iz 2018. godine utvrđeno je da će države članice do 2025 . godine „morati reciklirati najmanje 55\% komunalnog otpada, do 2030. najmanje 60\%, a do 2035. godine 65\%" (davorskrlec.eu 2019), dok će neke članice imati pravo zatražiti odgodu od pet 
VALENTINO PETROVIĆ

DISKURZIVNA ANALIZA ZAKONODAVNOG OKVIRA EUROPSKE UNIJE

O CIRKULARNOJ EKONOMIJI

godina ukoliko se nalaze u skupini država koje su 2013. godine reciklirale manje od 20\% komunalnog otpada ili odlagale više od 6o\% (Direktiva 2018/851 2018, 150/129).

U Direktivi o ambalaži i ambalažnom otpadu iz 2018. godine, jednako kao u prethodno analiziranoj, prevladava novi diskurs, što je jasno vidljivo u članku 1. u kojemu je naglasak na ponovnoj upotrebi ambalaže i recikliranju koji bi, naposljetku, trebali dovesti do transformacije ekoloških ciljeva prema modelu cirkularne ekonomije. U istome se članku u Direktivi 94/62/EZ iz 1994. godine navode tek prioriteti sprječavanja ambalažnog otpada, recikliranja i oporabe ambalaže, što treba rezultirati smanjenjem pojave takvog otpada na odlagalištima (Direktiva 2018/852 2018, 150/145) (Direktiva 94/62/EZ 1994, 14). Jednako tako, nova direktiva uvodi definicije ponovno uporabljive ambalaže i višeslojne (kompozitne) ambalaže, te se dodaju točke u kojima se preciziraju ciljevi za države članice. Tako do 2025. godine države članice Europske unije moraju reciklirati najmanje $65 \%$ ambalažnog otpada, dok se do 2030. godine taj postotak povećava na $70 \%$ (Direktiva 2018/852 2018, 150/147). Istaknuti su i posebni ciljevi za pojedine materijale. Do 2025 . godine mora se reciklirati „50\% plastike, $25 \%$ drveta, $70 \%$ neobojenih metala, 50\% aluminija, 70\% stakla, $75 \%$ papira i kartona“ (Direktiva 2018/852 2018, 150/147). Postotci su ponovno smanjeni u odnosu na one iz prethodnih paketa što upućuje na zaključak kako je Europska unija uzela u obzir razlike u mogućnostima provedbe ciljeva od strane država članica, te je svaka nova direktiva sadržajno specifičnija.

Posljednje dvije direktive: o odlagalištima otpada, odnosno o otpadnim vozilima, baterijama i akumulatorima, o otpadnim baterijama i akumulatorima, te otpadnoj električnoj i elektroničkoj opremi, sažetije su od prethodne dvije. Između ostalog, dodan je stavak prema kojem države članice do 2030. godine trebaju poduzeti mjere da se „sav otpad koji je pogodan za recikliranje ili drugi postupak oporabe, posebno komunalni otpad, ne prihvaća na odlagališta..." (Direktiva 2018/850 2018, 150/103). Jednako tako, određeno je da se do 2035. godine na odlagalištima količina komunalnog otpada smanji na 10\% (Direktiva 2018/850 2018, 150/104).

Direktive iz 2018. godine uokvirene su unutar novog, cirkularnog, diskursa te je vidljiva intencija Europske unije da se njima definiraju specifična područja na koje se cirkularnim mjerama može utjecati. Osim diskurzivnog pomaka kojim je cirkularna ekonomija ostvarila prve korake prema „samostalnosti“ u smislu odvajanja od široko shvaćene politike zaštite okoliša, što je vidljivo iz sadržaja direktiva i što će, između ostalog, biti rečeno $u$ provedenom intervjuu, $u$ analizi legislative Europske unije primjećuje se još jedan okvir. To je okvir unutar kojeg su istaknuta dva faktora: okoliš i ekonomija. Počevši od prvog paketa iz 2014. godine do direktiva iz 2018. godine, naglasak je na ekološkom (re)dizajnu, recikliranju, sorti- 


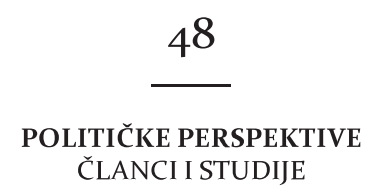

ranju otpada, odnosno na javnom i privatnom profitu, razvoju poduzetništva i otvaranju novih radnih mjesta. Ovaj rad će u analizu uključiti još jedan faktor koji će biti prikazan u diskusiji, a neophodan je za cjeloviti razvoj cirkularne ekonomije. Prije toga, promotrit ćemo kako se cirkularna ekonomija razvijala u Kini.

\section{EUROPSKA UNIJA I KINA - RAZLIKE U SHVAĆANJU MODELA CIRKULARNE EKONOMIJE}

U ovom poglavlju uspoređivat će se diskurs o cirkularnoj ekonomiji u Europskoj uniji i Kini, razlike u njihovim shvaćanjima kružnog modela i njegovih prioriteta, heterogenost aktera koji sudjeluju u donošenju ključnih odluka i, općenito, prikazat će se razvojni put cirkularne ekonomije u zakonodavstvu Kine. Razlog zašto govorimo o Kini leži u činjenici da u „globalnim razmjerima Kina ostvaruje najveću potrošnju prirodnih resursa i stvara najveće količine otpada" (Tišma i sur. 2017, 236), ali se istovremeno nalazi među državama predvodnicama korištenja kružnog modela.

Ideja cirkularne ekonomije u Kini se pojavljuje tijekom 1990-ih godina, ali 1998. biva prihvaćena kao koncept upravljanja okolišem, te početkom 20oo-ih dolazi do snažnijeg implementiranja u službene dokumente države (Qi i sur. 2016, 1). Kineski interes za cirkularnu ekonomiju u tom je razdoblju „bio potaknut njemačkim i japanskim zakonima o recikliranju" (Mathews i Tan 2016). Komparativno promatrano, Kina je započela s kreiranjem zakonodavnog i strateškog okvira cirkularne ekonomije prije Europske unije, stoga su i rezultati implementiranja takvog modela vidljiviji, dok na razini Europske unije policy ciklus implementacije tek treba započeti. Problemi okoliša i održivog razvoja u Kini i dalje postoje, ali „od 2005. do 2013. godine resursna učinkovitost porasla je za gotovo $35 \%$, intenzitet stvaranja otpada smanjen je za približno $47 \%$, a udio recikliranog i oporabljenog otpada porastao je za 8,2\%" (Tišma i sur. 2017, 237).

Cjelovita i kvalitetnija komparacija Europske unije i Kine bit će moguća nakon analize kvantitativnih podataka nastalih provedbom poduzetih mjera u Europskoj uniji jer su trenutno dostupni samo ciljevi koje je Unija predstavila državama članicama u sklopu paketa zakonodavnih reformi o cirkularnoj ekonomiji. Usprkos tome, Europskoj uniji i Kini je zajedničko prihvaćanje ekološkog minimuma i cirkularne ekonomije kao novog policy modela upravljanja resursima, te se „u obje regije cirkularna ekonomija predstavlja kao oblik ekološke modernizacije, ideja da se konfliktna shvaćanja između ekonomije i ekologije mogu prebroditi putem tehnološke i društvene inovacije" (McDowall i sur. 2017, 3)

Počeci razvoja cirkularne ekonomije u Kini obilježeni su aktivnim sudjelovanjem i doprinosom kineske akademske zajednice zahvaljujući 
VALENTINO PETROVIĆ

DISKURZIVNA ANALIZA ZAKONODAVNOG OKVIRA EUROPSKE UNIJE

O CIRKULARNOJ EKONOMIJI

kojoj je taj koncept isprva i uveden, te koja je zajedno s političkim i društvenim elitama potaknula razmišljanje o zagađenju okoliša kao važnom elementu daljnjeg ekonomskog razvoja (Qi i sur. 2016, 57). Kako je ranije navedeno, u Europskoj je uniji uloga akademske zajednice i europskih sveučilišta bila zanemarena, pa je većina tereta bila na ramenima upravo predstavnika Europske unije i njezinih istraživača, što je izrazito problematično s obzirom na široki broj aktera na koje problematika zagađenja okoliša utječe, odnosno koji mogu pridonijeti razvoju cirkularne ekonomije inovativnim rješenjima i metodama istraživanja. McDowall i sur. (2017) kao najveći problem Kine ističu njezin ubrzan ekonomski rast iz kojega proizlaze problemi vezani za shvaćanje i provedbu cirkularne ekonomije. Naime, Kina teško pronalazi ravnotežu između trenutnog ekonomskog rasta koji iziskuje velike ekološke gubitke i potreba da se cirkularna ekonomija implementira u značajnijoj mjeri. Za razliku od europskih država, Kina ima cilj zadržati trenutan rast. Europske države, s druge strane, žele potaknuti veći ekonomski rast putem inovacija kojima istovremeno nastoje poboljšati zaštitu sektora okoliša (McDowall i sur. 2017, 3). Isti autori navode da značajna razlika postoji i u načinu na koji se europske države i Kina odnose prema određenim pitanjima modela cirkularne ekonomije u policy dokumentima i medijima. Europske politike i dokumenti naglašavaju prednosti implementacije cirkularne ekonomije za industriju i u medijima je učestalo korištenje termina otpad (waste). U Kini je pozornost na stvaranju ekološki održive zajednice, odnosno ekološke civilizacije, te mediji u većoj mjeri koriste izraz zagađivanje (pollution) (McDowall i sur. 2017, 3-4). Geissdoerfer i sur., pak, pokazuju da razlike postoje i sa stajališta znanstvenog proučavanja navedene tematike. Tako je Kina država s najviše publikacija na temu cirkularne ekonomije; ima ih gotovo četiri puta više od prvog pratitelja, Engleske. Jednako tako, Kina je, kao ključna riječ, postala jedna od najpopularnijih odrednica pri pretraživanju publikacija o cirkularnoj ekonomiji (Geissdoerfer i sur. 2017, 76o).

Na policy razini Kina je donijela Zakon o promicanju cirkularne ekonomije, te su stvoreni fondovi za modernizaciju i olakšavanje provođenja cirkularnih mjera, čime se dodatno ističe holistički pristup Kine i suradnja s industrijskim tvrtkama na mikro, mezo i makro razini (Lacy i Rutqvist 2015, 173). Mathews i Tan navode ulogu države čije su intervencije, između ostalog, uključivale „fondove kojima se alocirala potpora konverziji industrijskih parkova u eko-industrijske aglomeracije. Porezne olakšice su omogućene tvrtkama koje prakticiraju ponovno korištenje resursa“ (Mathews i Tan 2016).

Međutim, empirijsko istraživanje (Liu i Bai 2014), koje je uključivalo provođenje upitnika i intervjue među 157 kineskih tvrtki, pokazalo je da postoji dihotomija između svijesti o važnosti implementacije načela cirku- 
larne ekonomije i konkretnih mjera poduzetih da se to ostvari. Naime, kineske tvrtke na teorijskoj razini prepoznaju cirkularnu ekonomiju kao model upravljanja politikom zaštite okoliša, ali u svome djelovanju ne pokazuju volju da te mjere provedu (Liu i Bai 2014, 150). Iz svega navedenog može se primijetiti da postoji značajna razlika između Europske unije i Kine kada govorimo o razvoju kružnog modela upravljanja ekonomijom. Pomalo ironično, pokazalo se da je Kina slijedila njemački primjer donošenja zakona o cirkularnoj ekonomiji, dok je Europska unija, čija je jedna od država osnivačica i ujedno njezina najvažnija članica Njemačka, s time krenula tek nakon 2011. godine. Naravno, moramo uzeti u obzir politički sustav, političku kulturu i stupanj centraliziranosti pri donošenju odluka u oba slučaja, no ipak ostaje mišljenje da je cirkularna ekonomija u Europskoj uniji mogla zaživjeti ranije, barem u kontekstu politike zaštite okoliša koja je imala, kako smo naveli, početni zamah u drugoj polovici 2o. stoljeća.

\section{DisKUSIJA}

Pregled dosadašnje literature o cirkularnoj ekonomiji i analiza tri paketa mjera kojima je Europska unija stvorila zakonodavni okvir oko iste te postavila obvezujuće ciljeve pred države članice omogućuje nam da uočimo tri razine diskursa o cirkularnoj ekonomiji koje su međusobno povezane i međusobno utječu jedna na drugu. Kao prvu razinu možemo promatrati odnos održivog razvoja i cirkularne ekonomije; druga je razina odnos okoliša i ekonomije; dok je treća razina intenzivnije usmjeravanje diskursa o cirkularnoj ekonomiji i njezinih prednosti na zdravlje ljudi.

Prva razina bila je kratko spomenuta prilikom samog definiranja cirkularne ekonomije, te smo uvidjeli da među autorima postoji opći konsenzus o odnosu održivog razvoja i cirkularne ekonomije. Međutim, radna definicija korištena u ovome radu ona je Geissdoerfera i sur. (2017) koji u obzir nisu uzeli samo sličnosti cirkularne ekonomije i održivog razvoja već, za našu analizu znatno važnije, njihove razlike. Svoju analizu potkrijepili su prikazom osam tipova odnosa u kojima se oni mogu naći (Geissdoerferr i sur. 2017, 764-765). Tako autori na početku tvrde da oba koncepta podrazumijevaju „multi- ili interdisciplinarni pristup za uspješniju integraciju neekonomskih aspekata u općeniti razvoj (...) naglašavaju važnost diverzifikacije (...) vide suradnju različitih aktera ne samo kao poželjnu, već kao imperativ (...) (i) smatraju inovacije u poslovnom sektoru ključnima" (Geissdoerferr i sur. 2017, 762-764). Osim toga, ponudili su skup distinkcija između dva koncepta, ali za argumentaciju koju ovaj rad slijedi najvažnija je ona da održivi razvoj ima opsežnije ciljeve, odnosno da je usmjeren jednako prema okolišu, ekonomiji i društvu, dok cirkularna ekonomija ipak prednost daje ekonomskim dobitima, zatim okolišu i tek 
VALENTINO PETROVIĆ

DISKURZIVNA ANALIZA ZAKONODAVNOG OKVIRA EUROPSKE UNIJE

O CIRKULARNOJ EKONOMIJI

na kraju društvu ili zajednici (Elkington 1997; Webster 2015 u: Geissdoerferr i sur. 2017, 764). Ovaj diskurs o razlikama između dva koncepta nam je važan jer, između ostalog, služi kao argument da je za uspješnu implementaciju principa cirkularne ekonomije i njezino de facto približavanje održivom razvoju neophodno naglasiti upravo čovjeka i kao prioritet postaviti zdravlje ljudi.

Druga razina koju promatramo, a izravno se nadovezuje na analizu zakonodavnog okvira Europske unije, jeste odnos okoliša i ekonomije. Sva tri paketa o cirkularnoj ekonomiji podrazumijevaju otvaranje novih radnih mjesta u državama članicama, povećanje konkurentnosti Europske unije i njezinih proizvoda, te stvaranje novih tehnologija kojima bi javni i privatni sektor istovremeno bili u mogućnosti ostvariti tržišne dobitke i podići razinu svijesti o cirkularnoj ekonomiji. Kada govorimo o javnom sektoru i načinu na koji se odnosi prema principima cirkularne ekonomije riječ je zapravo o državama članicama Europske unije. U zapadnom se dijelu Unije „odlaganje otpada smanjivalo tako da se koristilo spaljivanje otpada (kao metoda), što je prikazano kao uspjeh u smislu da se drastično smanjilo odlaganje otpada (...) dok $\mathrm{u}$ istočnom dijelu niti nisu bili razvijeni kapaciteti za spaljivanje..." (Škrlec, Davor, intervju, 03.09.2019).

Europska unija je smanjivanjem postotnih bodova za ispunjavanje ciljeva iz direktiva izašla u susret državama članicama, uzimajući u obzir razlike među njima, međutim, Škrlec ističe da su „ciljevi (iz direktiva iz 2018. godine) možda i zahtjevniji, nego oni iz 2014. godine (...) (jer je) obveza čistog materijala koji treba izaći iz postupka sortiranja i ući u postupak recikliranja puno zahtjevnija..." (Škrlec, Davor, intervju, 03.09.2019). Istovremeno, postavlja se pitanje kakva je uloga privatnog sektora u odnosu okoliša i ekonomije. Park i sur. (2010, 1495) u raspravu uvode teoriju ekološke modernizacije (ecological modernization theory) koja ima dublje implikacije od jednostavno shvaćenog win-win ili win-lose odnosa (Christmann 200o; Melnyk i sur. 2003; Hoffman i sur. 1999; Walley and Whitehead 1994 u: Park i sur. 2010, 1495). Tvrde da se teorijom ekološke modernizacije koja uključuje upravljanje lancima zelene nabave (green supply chain management) mogu postići tehnološke inovacije kojima će se povećati učinkovitost iskorištavanja resursa, te se ujedno može pomoći akterima u privatnom sektoru da u svome poslovanju adresiraju pitanja okoliša. Ova teorija, smatraju autori, ima obuhvatan pristup u odnosu na teoriju usmjerenu na resurse te su njezini rezultati vidljiviji što su potkrijepili primjerima tri kineske tvrtke ${ }^{8}$ koje su bile predmet njihove analize (Park i sur. 2010, 1495-1500). Škrlec, pak, napominje da u privatnom sektoru

8 Autori su proveli analizu studije slučaja tri kineske tvrtke Alcatel, Haier i Dongtai tijekom 20o8. godine, te su ispitivali uspješnost njihovog poslovanja u okviru teorije ekološke modernizacije s naglaskom na različite stupnjeve lanaca nabave (Park i sur. 2010). 
„postoji jedan progresivan dio koji shvaća da ako nastavimo ovim tempom trošiti resurse, a danas ih trošimo višestruko nego što Zemlja može regenerirati, vrlo brzo ćemo ih potrošiti za buduće generacije“, ali ostaje pitanje „kako skeptični dio privatnog sektora privući da počnu primjenjivati načela cirkularne ekonomije..." (Škrlec, Davor, intervju, 03.09.2019).

Treća razina koja proizlazi iz teorijskog pregleda i analize zakonodavstva Europske unije o cirkularnoj ekonomiji je ona koja u obzir uzima diskurs o zdravlju kao prioritetu pri ostvarivanju cirkularnog modela. U prvome paketu iz 2014. godine koji, naglašavamo, nije obvezujući dokument, već okvir unutar kojeg su definirani ciljevi i prioriteti nije bilo spomenuto zdravlje. Paket je bio najviše usmjeren na uvođenje mjera o otpadu i upravljanju resursima (eur-lex.europa.eu 2014). Analizirajući akcijski plan iz 2015. godine i usvojene direktive iz 2018. godine, ostaje dojam da je Europska unija ipak uzela u obzir učinak štetnog djelovanja zagađenja okoliša na zdravlje ljudi, makar se čini da su te promjene više deklarativne što, zapravo, slijedi ranije spomenutu argumentaciju Geissdoerferra i sur. (2017) o razlici između održivog razvoja i cirkularne ekonomije. Opravdanost treće razine može se povezati s tvrdnjom da „kada ljudi postanu svjesni da zagađenje utječe na njihovo zdravlje tada će promijeniti svoje ponašanje..." (Škrlec, Davor, intervju, 03.09.2019). Međutim, postavlja se pitanje kako diskurs o zdravlju nametnuti da bude polazišna osnova cirkularne ekonomije. Svaki problem ili javna politika dolazi na dnevni red odlučivanja na tri načina. Prvi se odnosi na

„davanje okvira problemu (issue framing), odnosno način na koji su pitanja definirana. Drugi faktor naglašava institucionalnu strukturu, ili mjesto javnih politika (policy venue) (...) Na kraju, važan je vremenski kontekst, ili prozor javnih politika (policy window) što označuje kratko vremensko razdoblje u kojem se pažnja posvećuje određenom problemu...” (Jerković i Petak 2017, 57).

Jerković i Petak (2017) navode primjer borbe protiv alkoholizma kao problem koji je u državama članicama Europske unije postojao tijekom 1990-ih, ali tada se nije percipirao kao problem, već kao posljedica slobodnog tržišta. Međutim, promjena se dogodila nakon što je Švedska preuzela predsjedanje Vijećem Europske unije 20o1. godine, te se pitanju alkoholizma pristupilo novim okvirom, čiji je naglasak na javnom zdravlju, pa je alkoholizam ubrzo postao zdravstveni i socijalni problem (Jerković i Petak 2017, 57-58). Tu se zapravo promatra mobilizacijski potencijal nekog problema ,jer njegovo postavljanje na agendu ovisi i o tome utječe li on na cjelokupno stanovništvo ili samo na neku manju skupinu..." (Petak i Petek 2014, 131). Stoga, može se tvrditi da je „postavljanje agende vjerojatno najvažnija faza u stvaranju javnih politika jer događaji u ovoj fazi imaju odlučujući utjecaj na ostatak ciklusa i njegov ishod“ (Jerković i 
VALENTINO PETROVIĆ

DISKURZIVNA ANALIZA ZAKONODAVNOG OKVIRA EUROPSKE UNIJE

O CIRKULARNOJ EKONOMIJI

Petak 2017, 49). Jednako tako, potrebno je imati i fokusirajući događaj (focusing event) (Versluis i sur. 2011, 116), što je u prethodnom primjeru bilo švedsko preuzimanje predsjedanja Vijećem Europske unije (Jerković i Petak 2017, 58). Stoga, nastavno na argument Škrleca o naglašavanju zdravlja ljudi kao poticaja za racionalnije upravljanje resursima i otpadom, možemo reći da se pitanju cirkularne ekonomije treba pristupiti na drugačiji način, odnosno da je potrebno promijeniti policy okvir ili ga redefinirati u smislu agende čime bi se potaknulo države članice, privatni sektor, civilna društva i građane da se bolje upoznaju sa samim kružnim modelom. Takva promjena uključivala bi naglašavanje negativnih posljedica zagađenja okoliša na zdravlje ljudi, čime bi se zdravlje kao faktor i prioritet izjednačilo s okolišnim i ekonomskim prednostima koji su najzastupljeniji u literaturi i dokumentima Europske unije.

\section{ZAKLJUČAK}

Ovaj rad za cilj je imao istražiti kako su se mijenjali prioriteti i diskurs unutar Europske unije kada je riječ o cirkularnoj ekonomiji i ponuditi odgovor na pitanje kako utjecati na svijest ljudi da promijene svoje shvaćanje cirkularnog modela ili se tek upoznaju s njime. To je učinjeno analizom zakonodavnog okvira Europske unije, počevši od prvog paketa o cirkularnoj ekonomiji iz 2014. godine, i pregledom dosadašnje literature o navedenoj problematici. U tome leži i doprinos rada jer su se u analizi nastojali prikazati temelji novog zakonodavstva Europske unije o cirkularnoj ekonomiji kojega čine četiri nove direktive, dok je u raspravi intencija bila kritički se osvrnuti na otvorena pitanja, odnosno različite diskurse unutar kojih se cirkularna ekonomija može dalje istraživati. Što se tiče odgovora na dva istraživačka pitanja s početka rada zaključujemo sljedeće.

Prioriteti zakonodavnog okvira Europske unije mijenjali su se unutar novostvorenog diskursa o cirkularnoj ekonomiji kao suvremenom načinu upravljanja resursima. Taj diskurs uključivao je paket iz 2014. s prijedlogom direktiva, akcijski plan iz 2015. te, konačno, paket iz 2018. s kojim su nove „cirkularne“ direktive usvojene. U analiziranim paketima i direktivama iz 2018. godine prisutan je snažan naglasak na ciljevima i očekivanjima od država članica, te su jasno definirani postotci koje trebaju ostvariti. Postotni ciljevi s godinama su se smanjivali, što je iz jedne perspektive logično s obzirom na različite mogućnosti provedbe tih ciljeva unutar država članica, njihov ekonomski razvoj, te interese ostalih aktera. Stoga, možemo reći da je danas oblikovan novi diskurs o cirkularnoj ekonomiji kao zasebnoj politici, izvan okvira politike zaštite okoliša, o čemu govori Škrlec kada kaže da je „cirkularna ekonomija nadrasla početni princip da se radi o zaštiti okoliša i da je ona potpuno novi ekonomski model“ 
(Škrlec, Davor, intervju, 03. 09. 2019). Pregledom i analizom dokumenata, te izvješća Europske unije, odnosno ekspertnim intervjuom pokazali smo da je učinjen neophodan diskurzivni iskorak prema ekonomskom faktoru jer promjene u prioritetima, ili postotnim ciljevima, upućuju da se unutar Europske unije razvilo novo shvaćanje potaknuto ekonomskim prednostima do kojih će doći implementacijom cirkularnog modela. Ali taj diskurzivni pomak nije potpun ukoliko se, osim okoliša i ekonomije, ne zadovolji posljednji faktor približavanja cirkularne ekonomije i održivog razvoja - društvo ili zajednica. To nas dovodi do drugog istraživačkog pitanja u kojem smo htjeli pokazati kako utjecati na promjene u ljudskoj svijesti i kako potaknuti aktere da prilagode obrasce svoga ponašanja maksimama cirkularnog modela.

Odgovor na to pitanje slijedio je tvrdnju Škrleca o ljudskom zdravlju kao faktoru, te je argumentacija utemeljena na procesu stavljanja javnih politika na dnevni red s posebnim naglaskom na fazu uokvirivanja problema (issue framing). Promatrajući idejne početke cirkularne ekonomije, zatim analizirane pakete, te kvalitativni i kvantitativni sadržaj direktiva, primjećuje se da su ciljevi na početku bili pretežno uokvireni oko pitanja okoliša, da bi se zatim diskurs proširio na ekonomski profit uvođenja cirkularnih mjera. Međutim, dugoročna održivost cirkularne ekonomije može se ostvariti promjenom policy okvira, odnosno novim diskurzivnim iskorakom prema zdravlju pojedinca i zajednice, kako je prikazano u diskusiji. Shvaćanju zdravlja kao ključnog faktora ide u prilog i primjer koji su u svojem radu naveli Lacy i Rutqvist (2015, 149-150). Autori su se pozvali na tvrdnju Guntera Paulija, autora knjige The Blue Economy, koji je opisao susret s direktorom tvrtke zadužene za proizvodnju kave. Kada ga je Pauli upitao što planira učiniti s ostacima kave, te planira li ih upotrijebiti za daljnju proizvodnju, npr. gljiva, direktor tvrtke mu je odgovorio da se ne bave gljivama, odnosno da će otpad od kave spaliti. Pauli navodi da se otpadom od kave može stvoriti nova vrijednost ili zdrava hrana (Lacy i Rutqvist 2015, 149-15o). Proces o kojem govori upravo je zaokruživanje proizvodnje i naglasak je na zdravlju, te implicitno zaštiti okoliša u vidu izbjegavanja spaljivanja i ekonomiji u vidu stvaranja nove vrijednosti, o kojima smo govorili kada smo diferencirali cirkularnu ekonomiju i održivi razvoj. Štoviše, Grundmann i sur. (2013) tvrde da su europski političari pristupili problemu kemijskog otpada tek kada su shvatili njegov poguban utjecaj na ljudsko zdravlje (Grundmann i sur. 2013, 2).

Ostaje dojam da se cirkularna ekonomija kao koncept pretjerano sublimirala, a zapravo ne postoji koherentno shvaćanje što ona zaista predstavlja. Prostor za daljnja istraživanja o ovoj temi ostaje otvoren, a prijedlog je da istraživači mogu ići u smjeru potrage za fokusirajućim događajem (focusing event). Osnivanje Zaklade Ellen MacArthur djelom je bio takav 
VALENTINO PETROVIĆ

DISKURZIVNA ANALIZA ZAKONODAVNOG OKVIRA EUROPSKE UNIJE

O CIRKULARNOJ EKONOMIJI

događaj, ali diskurs nije usmjeren na zdravlje ljudi. Usvajanje novih direktiva, kako se sada čini, neće dovesti do promjene mnijenja u tom smjeru. Ostaje za vidjeti hoće li ta promjena doći s top-down pristupom, koji bi uključio novi sastav Europskog parlamenta i Europske komisije ili, kao u prethodnom primjeru, predsjedanje Vijećem Europske unije neke od država članica zainteresirane za ovaj problem. Jednako tako, promjena može doći iz bottom-up smjera, što ipak zahtjeva veći angažman svih građana i deliberaciju o ekonomskim, okolišnim i zdravstvenim koristima cirkularne ekonomije.

\section{LITERATURA}

Andersen, Mikael Skou. 20o6. "An introductory note on the environmental economics of the circular economy”. Sustainability Science, 2(1): 133-140. doi: 10.1007/ s11625-0o6-0013-6.

Bačova, Martina, Kai Bohme, Marie Guitton, Marjan van Herwijnen, Tamas Kallay, Jenny Koutsomarkou, Ivano Magazzu, Eilish O'Loughlin and Ania Rok. 2016. "Pathways to a circular economy in cities and regions". ESPON, Interact, Interreg Europe and URBACT. https://espon.public.lu/dam-assets/publications/policybrief-on-circular-economy-final.pdf (accessed 13.03.2019).

Bilitewski, Bernd. 2012. "The Circular Economy and Its Risks". Waste Management, 32(1): 1-2. doi: 10.1016/j.wasman.2011.10.004

Bourguignon, Didier. 2016. "Closing the loop: New Circular Economy Package”. EPRS European Parliamentary Research Service. Members Research Service. http://www.europarl.europa.eu/RegData/etudes/BRIE/2016/573899/EPRS_ BRI(2016)573899_EN.pdf (accessed 13.03.2019).

Bourguignon, Didier. 2018. "Circular Economy Package: Four Legislative Proposals on Waste”. EPRS European Parliamentary Research Service. Members Research Service. https://www.europarl.europa.eu/RegData/etudes/BRIE/2018/625108/ EPRS_BRI(2018)625108_EN.pdf (accessed 24.10.2019).

Geissdoerfer, Martin, Paulo Savaget, Nancy M.P. Bocken and Erik Jan Hultink. 2017. “The Circular Economy - A New Sustainability Paradigm?" Journal of Cleaner Production, 143: 757-768. doi: 10.1016/j.jclepro.2016.12.048.

Grundmann, Veit, Bernd Bilitewski, Antje Zehm, Rosa Mari Darbra and Damia Barcelo. 2013. "Risk-based Management of Chemicals and Products in a Circular Economy at a Global Scale - Impacts of the $\mathrm{FP}_{7}$ Funded Projects RISKCYCLE”. Environmental Sciences Europe, 25 (14): 1-6.

Hollins, Oakdene, Peter Lee, Edward Sims, Olivia Bertham, Harry Symington, Nia Bell, Lucie Pfaltzgraff and Pernillia Sjogren. 2017. "Towards a circular economy - Waste management in the EU”. EPRS European Parliamentary Research Service. Science and Technology Options Assessment. http://www.europarl.europa.eu/RegData/etudes/STUD/2017/581913/EPRS_STU\%282017\%29581913_ EN.pdf (accessed 13.03.2019). 


\section{6 \\ POLITIČKE PERSPEKTIVE \\ ČLANCI I STUDIJE}

Hsieh, Hsiu-Fang and Shannon, Sarah E. 2005. "Three Approaches to Qualitative Content Analysis" Qualitative Health Research, 15(9): 1277-1288. doi: 10.117 7/1049732305276687.

Jerković, Dijana and Petak, Zdravko. 2017. "Setting the Policy Agenda for Combating the Abuse of New Psychoactive Substances in the Republic of Croatia". Criminology and Social Integration Journal, 25(2): 46-62. doi: 10.31299/ksi.25.2.5.

Kirchherr, Julian, Laura Piscicelli, Ruben Bour, Erica Kostense-Smit, Jennifer Muller, Anne Huibrechtse-Truijens, Marko Hekkert. 2018. "Barriers to the Circular Economy: Evidence From the European Union (EU)”. Ecological Economies, 150: 264-272. doi: 10.1016/j.ecolecon.2018.04.028.

Lacy, Peter and Rutqvist, Jakob. 2015. Waste to Wealth: The Circular Economy Advantage. London: Palgrave Macmillan.

Lahl, Uwe and Zeschmar-Lahl, Barbara. 2013. "Risk Based Management of Chemicals and Products in a Circular Economy at a Global Scale (Risk Cycle), Extended Producer Responsibility and EU Legislation". Environmental Sciences Europe, 25(3): 1-12. doi: 10.1186/2190-4715-25-3.

Liu, Yong and Bai, Yin. 2014. "An Exploration of Firms' Awareness and Behavior of Developing Circular Economy: An Empirical Research in China”. Resources, Conservation and Recycling, 87: 145-152. doi: 10.1016/j.resconrec.2014.04.002.

McCormick, John. 2010. Razumjeti Europsku uniju, 4. izdanje. Zagreb: MATE d.o.o. Biblioteka Gospodarska misao.

McDowall, Will, Yong Geng, Beijia Huang, Eva Bartekova, Raimund Bleischhwitz, Serdar Turkeli, Rene Kemp and Teresa Domenech. 2017. "Circular Economy Policies in China and Europe”. Journal of Industrial Ecology, 21(3). doi: 10.1111/ jiec.12597.

Park, Jacob, Joseph Sarkis and Zhaohui Wu. 2010. "Creating Integrated Business and Environmental Value within the Context of China's Circular Economy and Ecological Modernization". Journal of Cleaner Production, 18(15): 1494-1501. doi: 10.1016/j.jclepro.2010.06.001.

Petak, Zdravko i Petek, Ana. 2014. „Postavljanje dnevnog reda (agenda-setting)“. u: Ana Petek i Krešimir Petković. Pojmovnik javnih politika. Fakultet političkih znanosti Sveučilišta u Zagrebu: Biblioteka Političke analize.

Petak, Zdravko i Petek, Ana. 2014. „Proces stvaranja javnih politika (policy process)“. u: Ana Petek i Krešimir Petković. Pojmovnik javnih politika. Fakultet političkih znanosti Sveučilišta u Zagrebu: Biblioteka Političke analize.

Petković, Krešimir. 2014. „Diskurzivna analiza javnih politika (discursive policy analysis)“. u: Ana Petek i Krešimir Petković. Pojmovnik javnih politika. Fakultet političkih znanosti Sveučilišta u Zagrebu: Biblioteka Političke analize.

Preston, Felix. 2012. A Global Redesign? Shaping the Circular Economy. Chatam House EERG Briefing paper. London: The Royal Institute of International Affairs. 24.10.2019) https://www.chathamhouse.org/sites/default/files/public/ 


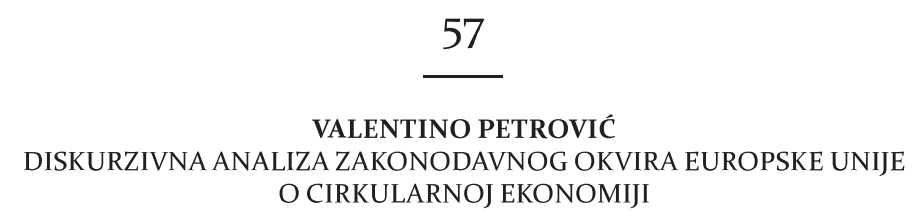

Research/Energy\%2C\%2oEnvironment\%2oand\%2oDevelopment/bpo312_preston.pdf (accessed 24.10.2019).

Scharff, Christoph. 2018. "The EU Circular Economy Package and the Circular Economy Coalition for Europe". https://www.cec4europe.eu/wp-content/uploads/2018/o9/Scharff-The-EU-Circular-Economy-Package-and-CEC4Europe_2018.pdf (accessed 24.10.2019).

Tišma, Sanja, Ana-Maria Boromisa, Marina Funduk i Helena Čermak. 2017. Okolišne politike i razvojne teme. Alineja: Zagreb.

Vromen, Ariande. 2018. “Qualitative Methods”, in: Vivien Lowndes, David Marsh and Gerry Stoker. Theory and Methods in Political Science. Palgrave: London.

Qi, Jianguo, Jingxing Zhao, Wenjun Li, Xushu Peng, Bin Wu, Hong Wang, Fengling Jia, Tong Yang and Haiying Qi. 2016. Development of Circular Economy in China. Singapore: Social Sciences Academic Press and Springer Science.

Wysokinska, Zofia. 2016. “The 'New' Environmental Policy of the European Union: A Path to Development of a Circular Economy and Mitigation of the Negative Effects of Climate Change". Comparative Economic Research, 19(2): 5773. doi: 10.1515/cer-2016-oo13.

Zaklada Ellen MacArthur, World Economic Forum, McKinsey \& Company. 2014. Towards The Circular Economy: Accelerating The Scale-up Across Global Supply Chains. Vol. 3.

Zaklada Ellen MacArthur. 2013. Towards The Circular Economy: Economic and Business Rationale for an Accelerated Transition. Vol. 1.

Zaklada Ellen MacArthur. 2013. Opportunities for the Consumer Goods Sector. Vol. 2.

\section{INTERNETSKE STRANICE}

davor-skrlec.eu (2018) Davor Škrlec: zastupnik u Europskom parlamentu. Rok za prilagodbu zakonodavstva Republike Hrvatske za prelazak na kružno gospodarstvo https://www.davor-skrlec.eu/rok-za-prilagodbu-zakonodavstva-republikehrvatske-za-prelazak-na-kruzno-gospodarstvo/ (pristupljeno 21. 07. 2019).

ec.europa.eu (2019) Europska komisija: Prema kružnom gospodarstvu https:// ec.europa.eu/commission/priorities/jobs-growth-and-investment/towardscircular-economy_hr (pristupljeno 09. 03. 2019).

ellenmacarthurfoundation.org (2019) Schools of Thought https://www.ellenmacarthurfoundation.org/circular-economy/concept/schools-of-thought (pristupljeno 29. 10. 2019).

ellenmacarthurfoundation.org (2019) Mission https://www.ellenmacarthurfoundation.org/our-story/mission (pristupljeno 29. 10. 2019).

ellenmacarthurfoundation.org (2019) Publications https://www.ellenmacarthurfoundation.org/publications (pristupljeno 29. 10. 2019). 
POLITIČKE PERSPEKTIVE

ČLANCI I STUDIJE

europa.eu (2015) European Commission. Press Database Release https://europa. eu/rapid/press-release_IP-15-6203_hr.htm (pristupljeno 03. 11. 2019).

europarl.europa.eu (2019) Europski parlament. Zastupnici: Davor Škrlec. http:// www.europarl.europa.eu/meps/hr/124756/DAVOR_SKRLEC/history/8 (pristupljeno 23. 10. 2019).

Mathews, John A. i Tan, Hao (2016) Circular Economy: Lessons from China. Nature.com. https://www.nature.com/news/circular-economy-lessons-from-china1.19593 (pristupljeno 15. 07. 2019).

\section{DOKUMENTI}

EUR-Lex (Access to European Union Law) (2019) Izvješće Komisije Europskom parlamentu, Vijeću, Europskom gospodarskom i socijalnom odboru i Odboru regija. O provedbi akcijskog plana za kružno gospodarstvo. https://eur-lex. europa.eu/legal-content/HR/TXT/PDF/?uri=CELEX:52019DCo19o\&from=HR (pristupljeno 24. 10. 2019).

EUR-Lex (Access to European Union Law) (2018) Komunikacije Komisije Europskom parlamentu, Vijeću, Europskom gospodarskom i socijalnom odboru i Odboru regija. O okviru za praćenje kružnog gospodarstva. https://eur-lex. europa.eu/legal-content/HR/TXT/PDF/?uri=CELEX:52018DCoo29\&from=EN (pristupljeno 20. 07. 2019).

EUR-Lex (Access to European Union Law) (2014) Komunikacija Komisije Europskom parlamentu, Vijeću, Europskom gospodarskom i socijalnom odboru i Odboru regija. Prema kružnom gospodarstvu: program nulte stope otpada za Europu. https://eur-lex.europa.eu/legal-content/HR/TXT/PDF/ ?uri=CELEX:52014DCo398R(o1)\&from=HR (pristupljeno 15. 07. 2019).

EUR-Lex (Access to European Union Law) (2015) Komunikacija Komisije Europskom parlamentu, Vijeću, Europskom gospodarskom i socijalnom odboru i Odboru regija. Zatvaranje kruga - akcijski plan EU-a za kružno gospodarstvo. https://eur-lex.europa.eu/resource.html?uri=cellar:8a8ef5e8-99ao-11e5-b3b7o1aa75ed71a1.0023.02/DOC_1\&format=PDF (pristupljeno 13. 03. 2019).

EUR-Lex (Access to European Union Law) (2014) Prijedlog direktive Europskog parlamenta i Vijeća o izmjeni direktiva 2008/98/EZ o otpadu, 94/62/EZ o ambalaži i ambalažnom otpadu, 1999/31/EZ o odlagalištima otpada, 2000/53/EZ o otpadnim vozilima, 2006/66/EZ o baterijama i akumulatorima i o otpadnim baterijama i akumulatorima, te 2012/19/EU o otpadnoj električnoj i elektroničkoj opremi. https://eur-lex.europa.eu/resource.html?uri=cellar:e669092f-o1e1-11e4831f-o1aa75ed71a1.0019.02/DOC_1\&format=PDF (pristupljeno 24. 10. 2019). 
VALENTINO PETROVIĆ

DISKURZIVNA ANALIZA ZAKONODAVNOG OKVIRA EUROPSKE UNIJE

O CIRKULARNOJ EKONOMIJI

\section{DiREKTIVE}

EUR-Lex (Access to European Union Law) Direktiva 2008/98/EZ Europskog parlamenta i Vijeća od 19. studenoga 20o8. o otpadu i stavljanju izvan snage određenih direktiva. https://eur-lex.europa.eu/legal-content/HR/TXT/PDF/ ?uri=CELEX:32008Loo98\&from=HR (pristupljeno 24. 10. 2019).

EUR-Lex (Access to European Union Law) Direktiva Europskog parlamenta i Vijeća 94/62/EZ od 20. prosinca 1994. o ambalaži i ambalažnom otpadu. https://eurlex.europa.eu/legal-content/HR/TXT/PDF/?uri=CELEX:31994Loo62\&from=HR (pristupljeno 25. 10. 2019).

EUR-Lex (Access to European Union Law) Direktiva (EU) 2018/851 Europskog parlamenta i Vijeća od 3o. svibnja 2018. o izmjeni Direktive 2008/98/ EZ o otpadu. https://eur-lex.europa.eu/legal-content/HR/TXT/PDF/ ?uri=CELEX:32018Lo851\&from=hr (pristupljeno 24. 10. 2019).

EUR-Lex (Access to European Union Law) Direktiva (EU) 2018/852 Europskog parlamenta i Vijeća od 30. svibnja 2018. o izmjeni Direktive 94/62/EZ o ambalaži i ambalažnom otpadu. https://eur-lex.europa.eu/legal-content/HR/TXT/PDF/ ?uri=CELEX:32018Lo852\&from=hr (pristupljeno 24. 10. 2019).

EUR-Lex (Access to European Union Law) Direktiva (EU) 2018/850 Europskog parlamenta i Vijeća od 30. svibnja 2018. o izmjeni Direktive 1999/31/EZ o odlagalištima otpada. https://eur-lex.europa.eu/legal-content/HR/TXT/PDF/ ?uri=CELEX:32018Lo850\&from=HR (pristupljeno 24. 10. 2019).

EUR-Lex (Access to European Union Law) Direktiva (EU) 2018/849 Europskog parlamenta i Vijeća od 30. svibnja 2018. o izmjeni Direktiva 2000/53/EZ o otpadnim vozilima, 2006/66/EZ o baterijama i akumulatorima i o otpadnim baterijama i akumulatorima, te 2012/19/EU o otpadnoj električnoj i elektroničkoj opremi. https://eur-lex.europa.eu/legal-content/HR/TXT/PDF/ ?uri=CELEX:32018Lo849\&from=hr (pristupljeno 24. 10. 2019).

\section{SUMMARY}

\section{Discourse ANALYSIS OF THE LEgISLATIVE FrameWORK OF THE EUROPEAN UNION ON CiRCUlar ECONOMY}

The latest research on circular economy development in the European Union were primarily directed towards the advantages of implementation of such model which are most commonly presented as environmental and economic. This paper analyzes the circular economy discourse from a different point of view, one that focuses on human health as crucial element. In line with that, the paper will answer two questions; how did priorities and discourses within the legislative framework in the European Union had changed, and how to raise awareness of main actors to adapt their behaviour and actions towards environmental norms. The paper uses text and discourse analysis by which the current literature and documents of the European Union will be addressed, 
primarily the EU packages on circualr economy, 2015 Action Plan and newly adopted directives. Also, comparative method is used for comparison of "old" and "new" directives and discourses between the European Union and China . The last method used is interview conducted with Davor Škrlec, former Member of European Parliament and member of Greens/European Free Alliance political group. The results have shown that each new package on circular economy was more precise regarding quality but the proclaimed goals were alligned with implementation capacities of member states. Thus, a new discourse on circular economy was formed but in order it to be systematically implemented there is a need to emphasize human health as its main priority.

KEYWORDS: circular economy, European Union, directive $2018 / 851$ on waste, China, policy, discourse analysis. 